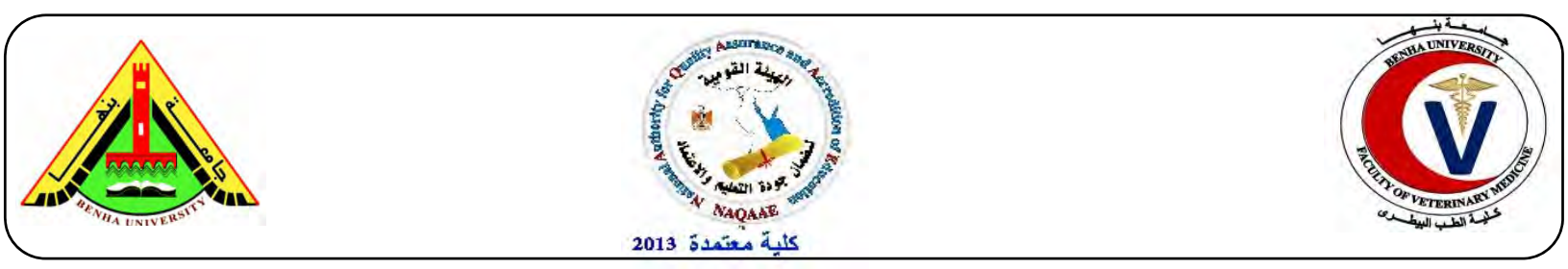

\title{
Effect of pH, heat treatments and proteinase $K$ enzyme on the activity of Lactobacillus Acidophilus bacteriocin
}

\author{
Marwa A. Saad ${ }^{1}$, Hamdi M. Abdelsamei ${ }^{1}$, Ekbal M. A.Ibrahim ${ }^{1}$, Adham M. Abdou ${ }^{1}$, Sobhy A. El \\ Sohaimy ${ }^{2}$ \\ ${ }^{1}$ Department of Food Control, Fac. of Vet. Med., Benha Univ., Egypt. \\ ${ }^{2}$ Food Technology Department arid land research institute city of scientific Research and technology \\ application
}

\section{A B S T R A C T}

Bacteriocins are natural metabolites produced by many strains of Lactic acid bacteria that used in food preservation. They have potential healthy role in suppressing the growth of some spoilage and pathogenic bacteria. The aim of the current study was to demonstrate the stability of the bacteriocin extracted from Lactobacillus acidophilus at different $\mathrm{pH}$ values, heat treatments and proteinase $\mathrm{K}$ enzyme. The obtained results revealed that the inhibitory effectiveness of bacteriocins was higher on Gram-positive bacteria than Gram-negative bacteria. Further, the largest inhibition zone was obtained by L acidophilus bacteriocin against Bacillus subtilis while the smallest one was against E.coli. The extracted bacteriocin exhibited broad spectrum of inhibition at concentration 6400AU/ml against Staph. aureus, Bacillus subtilis and E.coli. The antimicrobial activity of crude supernatant fluid was stable after heating at $100^{\circ} \mathrm{C}$ for $30 \mathrm{~min}$ and declined thereafter. Stability of antimicrobial activity was observed at $\mathrm{pH}$ ranged from 2.0 to 8.0. Its active principle was proteinaceous in nature since the bacteriocin was inactivated by proteinase $\mathrm{K}$ enzyme.

Keywords: Bio preservation, Lactic acid bacteria, Lactobacillus acidophilus, Bacteriocin and Antimicrobial activity.

\section{INTRODUCTION}

Increasing demands by consumers for natural and chemical-free food products have led the food industry to search for a new novel and alternative strategies for food biopreservation (Cosentino et al., 2012). Among these alternatives, the bacteriocins which are defined as ribosomally-synthesized peptides or proteins with antimicrobial activity against many food-borne pathogens and spoilage bacteria in foods (Muñoz et al., 2007). They are produced by different strains of lactic acid bacteria (LAB) such as Lactococcus, Pediococcus, Leuconostoc, Enterococcus and Lactobacillus (Mc Auliffe et al., 2001). Bacteriocins have several potential characteristics rendering them useful natural food preservatives as they are small hydrophobic cationic peptides, stable at a wide range of $\mathrm{pH}$, temperature and considered as Generally Recognized as Safe (GRAS) by FDA (Cleveland et al., 2001). Lactobacillus acidophilus is the most important $\mathrm{LAB}$ used for production of bacteriocin (Bogovic Matijasic et al., 1998). It is widely used for production of fermented dairy products in the world and it is one of probiotic bacteria. Probiotic microorganisms are thought to counteract disturbances in the normal microflora and thereby reduce the risk of colonisation by pathogenic bacteria (Sullivan et al., 2001). Several theories have been proposed to explain the antimicrobial and beneficial effects of probiotics, including their capacity to compete for nutrients and their 
ability to secrete antimicrobial substances such as organic acids, bacteriocins and peptides (Ljungh and Wadström, 2006). Previous studies of probiotics have been demonstrated an impressive increase in the interest of $L$. acidophilus as a probiotic agent, and have contributed to its application in functional food and supplements in a worldwide market (Naidu et al., 1999; Kitazawa et al., 2002). Lactobacillus acidophilus DSM 20079 produces a heat-stable peptide bacteriocin named acidocin D20079, active over a wide range of $\mathrm{pH}$, with suitable properties for use in the food industry (Deraz et al., 2005). The addition of bacteriocin of $L$. acidophilus DSM 20079 to plain yoghurt can improve organoleptic characters, enhance microbial safety and prolonge the shelf life of plain yoghurt up to 28 days (Awad, 2011). In the present study, L. acidophilus was activated and its bacteriocin was extracted to detect its stability at different heat treatments, $\mathrm{pH}$ values and proteinase $\mathrm{K}$ enzyme.

\section{MATERIAL AND METHODS}

\subsection{Activation of Lactobacillus acidophilus:}

Lyophilized strain of L. acidophilus DSM 20079 was obtained from MIRCEN (Microbiological Resource Center), Faculty of Agriculture, Ain Shams University, Cairo, Egypt. Lactobacillus acidophilus strain was activated on MRS broth (De Man, Rogosa and Sharp which obtained from Biolife, Italy) at $37^{\circ} \mathrm{C}$ for 24 hours then 3 transfers were performed to activate this culture. Decimal serial dilutions were prepared till obtaining the concentrations of $10^{7}-10^{9} \mathrm{CFU} / \mathrm{mL}$ in order to meet the required recommended level for active probiotic (IDF, 1988).

\subsection{Extraction of bacteriocin:}

Ten $\mathrm{mL}$ of activated culture of $L$. acidophilus was separately inoculated into one liter of MRS broth under aseptic conditions (Chumchalova et al., 2004).
Bacteriocin producing culture was adjusted to $\mathrm{pH} 2.0$ by adding $\mathrm{HCl} 1 \mathrm{~N}$ then culture was heated in a water bath at $100{ }^{0} \mathrm{C}$ for 5 min. The cells were harvested by centrifugation at $10,000 \mathrm{rpm}$ for $20 \mathrm{~min}$ at $4^{0} \mathrm{C}$. The cell-free supernatant containing bacteriocin extract was adjusted to $\mathrm{pH} 6.0$ using $\mathrm{NaOH} 1 \mathrm{M}$ to exclude the effect of organic acids. The bacteriocin extract was sterilized by using Seitz filter to eliminate the probability of presence of viable cells (Simova et al., 2009).

\subsection{Characterization of Bacteriocin:}

The crude bacteriocin extracted from $L$. acidophilus DSM 20079 was examined for stability to $\mathrm{pH}$, heat treatments and proteolytic enzyme as follows:

\subsubsection{Effect of $p H$ values:}

Accurately, $5 \mathrm{ml}$ of crude bacteriocin was taken into different test tubes and the $\mathrm{pH}$ values were adjusted to $\mathrm{pH} 2,4,6,8,10$ and 12 , using either $1 \mathrm{~N} \mathrm{HCl}$ or $1 \mathrm{M} \mathrm{NaOH}$. The samples were incubated at $28^{\circ} \mathrm{C}$ for 16 hours and then the bacteriocin activity was determined by using agar well diffusion method (Ogunbanwo et al., 2003).

\subsubsection{Effect of heat:}

A volume of $5 \mathrm{ml}$ from crude bacteriocin was exposed to various heat treatments (40, $60,80,100^{\circ} \mathrm{C}$ for $30 \mathrm{~min}$ ) in thermostatic water bath and $121^{\circ} \mathrm{C}$ for $15 \mathrm{~min}$ in autoclave. The bacteriocin activity was then assayed by agar well diffusion method (Ogunbanwo et al., 2003, Rajaram et al., 2010).

\subsubsection{Effect of Proteinase K enzyme:}

To test the sensitivity to proteinase $\mathrm{K}$ enzyme, aliquots of $1 \mathrm{ml}$ of crude bacteriocin was treated with proteinase $\mathrm{K}$ (Sigma, St. Louis, USA) at a concentration of $1 \mathrm{mg} / \mathrm{ml}$ at $\mathrm{pH} 7$. The test tubes with and without the enzyme (control) were incubated at $37^{\circ} \mathrm{C}$ for 2 hours and then heated at $100^{\circ} \mathrm{C}$ for $3 \mathrm{~min}$ to denature the enzyme. Both control and treated samples 
were assayed for antimicrobial activity by using agar well diffusion method (Neha and Nivedita, 2009).

\subsection{Statistical analysis:}

Statistical comparisons were made by using one-way analysis of variance (ANOVA). The results were considered significantly different with $\mathrm{P}<0.05$ as described by Clarke and Kempson (1997).

\section{RESULTS}

Bacteriocins are generally of low molecular weight proteins with bactericidal effect on Gram-positive bacteria and bacteriostatic action on Gram-negative bacteria (O'Sullivan et al., 2002).

\subsection{Effect of $p H$ :}

The effect of different $\mathrm{pH}$ values (2-12) on the activity of crude bacteriocin of $L$. acidophilus were presented in Table (1). The sensitivity of crude bacteriocin to different $\mathrm{pH}$ values was examined and it was very stable over a wide $\mathrm{pH}$ range $(2,4$, 6 and 8). The inhibition zones of indicator bacteria Staph. aureus, Bacillus subtilis and E.coli measured by agar well diffusion method.

\subsection{Effect of heat:}

The effect of different temperature on the activity of $L$. acidophilus DSM 20079 is presented in fig (1). Regarding to the effect of temperature on the stability, $L b$. acidophilus bacteriocin was heat stable to heat treatment up to $80^{\circ} \mathrm{C}$ for $30 \mathrm{~min}$. The activity of the bacteriocin was completely disappeared by heating at $121^{\circ} \mathrm{C}$ for $15 \mathrm{~min}$.

\subsection{Effect of proteolytic enzyme:}

Table (2) showed the effect of proteinase K on the activity of crude bacteriocin of $L$. acidophilus DSM 20079. The activity was completely disappeared by the treatment with proteinase $\mathrm{K}$.

Table (1): Effect of $\mathrm{pH}$ values on the stability of bacteriocin extracted from L. acidophilus DSM 20079.

\begin{tabular}{|c|c|c|c|}
\hline \multirow[b]{2}{*}{ PH values } & \multicolumn{3}{|c|}{ Diameter of inhibition zone (mm) } \\
\hline & Staph. Aureus & Bacillus subtilis & E.coli \\
\hline Control (6.6) & $12 \pm 0.39^{b}$ & $14 \pm 0.57^{\mathrm{a}}$ & $10 \pm 0.24^{\mathrm{c}}$ \\
\hline 2 & $12 \pm 0.39^{b}$ & $14 \pm 0.57^{\mathrm{a}}$ & $10 \pm 0.24^{\mathrm{c}}$ \\
\hline 4 & $12 \pm 0.39^{b}$ & $14 \pm 0.57^{\mathrm{a}}$ & $10 \pm 0.24^{\mathrm{c}}$ \\
\hline 6 & $12 \pm 0.39^{b}$ & $14 \pm 0.57^{\mathrm{a}}$ & $10 \pm 0.24^{\mathrm{c}}$ \\
\hline 8 & $12 \pm 0.39^{\mathrm{b}}$ & $14 \pm 0.57^{\mathrm{a}}$ & $10 \pm 0.24^{\mathrm{c}}$ \\
\hline 10 & $7.34 \pm 0.18^{b}$ & $9.5 \pm 0.25^{\mathrm{a}}$ & $4.35 \pm 0.14^{\mathrm{c}}$ \\
\hline 12 & ND & ND & ND \\
\hline
\end{tabular}

$\mathrm{a}, \mathrm{b}, \mathrm{c}$ mean values in the same raw having different superscripts letters are significantly different $(P<0.05)$. Control: bacteriocin without treatment. ND not detected. Results are mean of three determination $(n=3)$.

Figure (1) Effect of heat treatments on the stability of bacteriocin

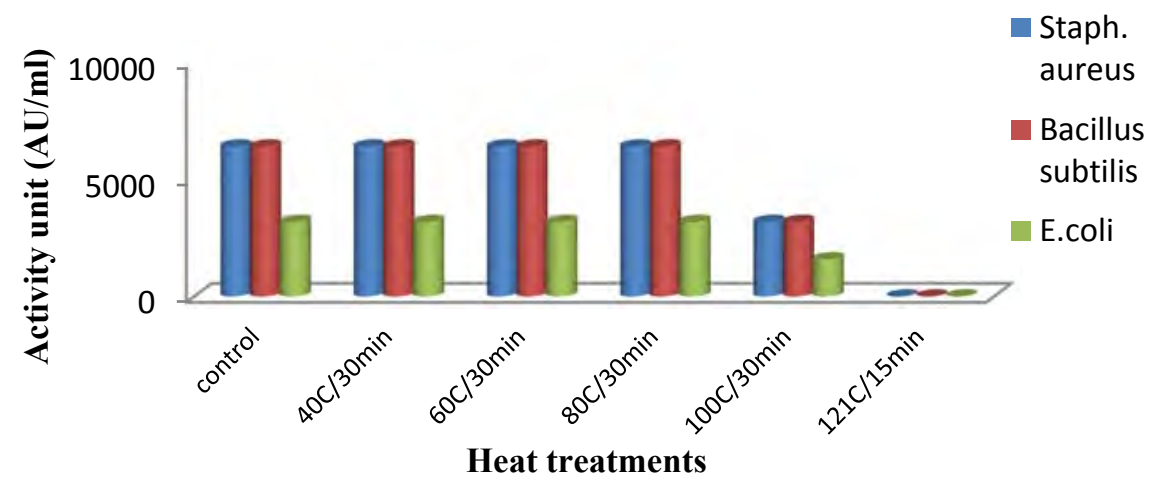


Table (2) Effect of proteinase K enzyme on the stability of bacteriocin

\begin{tabular}{lccc}
\hline \multicolumn{4}{c}{ Diameter of inhibition zone $(\mathrm{mm})$} \\
\hline Enzyme treatment & Staph. aureus & Bacillus subtilis & E.coli \\
Control & 12.56 & 15.46 & 11 \\
Proteinase K & ND & ND & ND \\
\hline bacteriocin without enzyme treatment. ND not detected. Results are mean of three determination $(\mathrm{n}=3)$
\end{tabular}

\section{DISCUSSION}

Lactic acid bacteria are used in the food industry due to their ability to ferment carbohydrates into lactic acid and, as a consequence, reduce the $\mathrm{pH}$ of the medium. This acidification is one of the most desirable effects of $\mathrm{LAB}$ fermentations because it prevents the growth of undesirable bacteria and thus prolonging the shelf life, aroma, texture and flavor of the food (Du Toit et al., 2000). Preservation of fermented foods by LAB is mainly due to the production of organic acids and other compounds such as bacteriocins which have a potential role to inhibit a variety of harmful microorganisms (Daeschel, 1989; De Vuyst and Leroy, 2007). During characterization of bacteriocin produced from L. acidophilus DSM 20079; the antimicrobial activity was determined using Staph. aureus, Bacillus subtilis and E.coli as indicator organisms. Regarding to the effect of $\mathrm{pH}$ values on the activity of the bacteriocins extracted from L. acidophilus, the activity of bacteriocins were very stable over a wide range of $\mathrm{pH}(2,4,6$ and 8$)$, which was recorded by the diameter of inhibition zone $(\mathrm{mm})$ with mean values of $14 \pm 0.57,12 \pm 0.39$ and $10 \pm 0.24 \mathrm{~mm}$ against B. subtilis, Staph. aureus and E. coli, respectively. While, its activity slightly decreased by increasing $\mathrm{pH}$ value up to 10 with inhibition zone $9.5 \pm 0.25,7.34 \pm 0.18$ and $4.35 \pm 0.14 \mathrm{~mm}$ against $B$. subtilis, Staph. aureus and E. coli, respectively. In contrast, the activity of bacteriocins was completely disappeared at $\mathrm{pH} 12$ as shown inTable (1). This bacteriocin was stable over a wide $\mathrm{pH}$ range, which is a common feature of many bacteriocins as reported by (Ogunbanwo et al., 2003; Corsetti et al. 2004; Rattanachaikunsopon and Phumkhachorn (2006) \& Todorov and
Dicks, 2006). The wide range of $\mathrm{pH}$ tolerance indicates that such bacteriocin may be useful in acidic as well as non-acidic foods. Temperature stability is important if the bacteriocins are to be used as a food preservative, because many procedures of food preparation involve a heating step. Fig (1) showed the activity of bacteriocin of $L$. acidophilus DSM20079 after heat treatment up to $80^{\circ} \mathrm{C}$ for $30 \mathrm{~min}$ was stable and it was 6400AU/ml, but its activity was declined after heating at $100^{\circ} \mathrm{C}$ for $30 \mathrm{~min}$ to be 3200 $\mathrm{AU} / \mathrm{ml}$. The activity of bacteriocin by autoclaving at $121^{\circ} \mathrm{C}$ for $15 \mathrm{~min}$ was disappeared. The phenomenon of heat stability of bacteriocin from different LAB at $121^{\circ} \mathrm{C}$ for $15 \mathrm{~min}$ has been reported earlier in Lactocin RN 78 (Mojgani and Amirinia, 2007) and in L.brevis OGI (Ogunbanwo et al., 2003) whom reported similar results with our finding loss of activity of antibacterial substances produced by Lactobacillus spp. after heat treatment at $121^{\circ} \mathrm{C}$ for different time duration. In respect to the temperature stability, the examined bacteriocin exhibited strong heat stability, which means it could be placed within the heat stable low molecular weight group of bacteriocins. The antimicrobial activity of extracted bacteriocin was destroyed by treatment with proteinase $\mathrm{K}$ as there was no inhibition zone appeared compared with the untreated bacteriocin sample (control). Similar results were reported by Corsetti et al. (2004); Todorov and Dicks (2004); Hernandez et al. (2005); Rattanachaikunsopon and Phumkhachorn (2006). The sensitivity of the extracted bacteriocin to proteolytic enzymes is approving the proteinaceous nature of bacteriocin (Deraz et al., 2005). As conclusion, L. acidophilus bacteriocin was characterized by high stability at different 
$\mathrm{pH}$ values, heat treatments, and completely inactivation by proteinase $\mathrm{K}$ enzyme. Accordingly, the ability of bacteriocin, produced by L. acidophilus, for inhibiting a

\section{REFERENCES}

Awad, M.M. 2011. Effect of bacteriocins produced by some lactic acid bacteria on the quality of yoghurt. M.V.Sc. Thesis, Faculty of Veterinary Medicine, Banha University. Egypt.

Borpuzari, R.N., Borpuzari, T., Deuri, B. 2007. Probiotic characteristics of Lactobacillus acidophilus strains isolated from fermented milk. Journal of Food Science and Technology 44(2): 158-160.

Chumchalova, J., Josephsen, J., Plockova, M. 2004. Characterization and purification of acidocin $\mathrm{CH} 5$, a bacteriocin produced by Lactobacillus acidophilus CH5. Journal of Applied Microbiology 96:1082-1089.

Clarke, G.M., Kempson, R.E. 1997. Introduction to the design and analysis of experiments. Arnold, a Member of the Holder Headline Group. 1 st ed., London, UK.

Cleveland, J., Montville, T.J., Nes, I.F., Chikindas, M.L. 2001. Bacteriocins: Safe, natural antimicrobials for food preservation. International Journal of Food Microbiology 71: 1-20.

Coeuret, V., Dubernet, S., Bernardeau, M. 2003. Isolation, characterization and identification of lactobacilli focusing mainly on cheeses and other dairy products. Lait 83: 269- 306.

Corsetti, A., Settanni, L., VanSinderen, D. 2004. Characterizations of bacteriocin like inhibitory (BLIS) from sourdough lactic acid bacteria and evaluation of their in vitro and in situ activity. Journal of Applied Microbiology 96: 521-534.

Cosentino, S., Fadda, M.E., Deplano, M., Melis, R., Pomata, R., Pisano, M.B. 2012. Antilisterial activity of nisin-like bacteriocin-producing Lactococcus wide-range of bacteria may be of potential interest for food safety and preservation providing future scope for application as food preservative.

lactis subsp. lactis isolated from traditional Sardinian dairy products. Journal of Biomedicine and Biotechnology.

Daeschel, M.A. 1989. Antibacterial substances from lactic acid bacteria for use as food preservatives Journal of Food Technology 43: 164-167.

Deraz, S., Karlsson, N.E., Hedstrom, M., Andersson, M.M., Mattiasson, B. 2005. Purification and characterization of acidocin D20079 a bacteriocin produced by Lactobacillus acidophilus DSM 20079. Journal of Biotechnology 117: 343-354.

De Vuyst, L., Leroy, F. 2007. Bacteriocins from Lactic Acid Bacteria: Production, Purification and Food Applications. Journal of Molecular Microbiology 13: 194-199.

Du Toit, M., Franz, C.M.A.P., Disks, L.M.T., Holzapfel, W.H. 2000. Preliminary characterization of bacteriocins produced by Enterococcus faecium and Enterococcus fecalis isolated from pig faeces. Journal of Applied Microbiology 88: 482-494.

Hernandez, D., Cardell, E., Zarate, V. 2005. Antimicrobial activity of lactic acid bacteria isolated from Tenerife cheese: initial characterization of plantaricin TF711, a bacteriocin-like substance produced by Lactobacillus plantarum TF711. Journal of Applied Microbiology 99: 77-84.

IDF (International Dairy Federation); 1988. Fermented milks: Science and technology. Bulletin of the IDF: In A. No. 227, Brussels.

Kitazawa, H., Ino, T., Kawai,Y., Itoh, T., Saito, T. 2002. A novel immune stimulating aspect of Lactobacillus gasseri: induction of 'Gasserokine' as chemo attractants for macrophages. 
International Journal of Food Microbiology 77: 29-38.

Ljungh, A.,Wadström, T.2006. Lactic acid bacteria as probiotics. Current Issues Intestinal Microbiology 7: 73-89.

Mc Auliffe, O., Ross, R.P., Hill, C. 2001. Lantibiotics structure, biosynthesis and mode of action. FEMS Microbiology Review 25: 285-308.

Mojgani, N., Amirinia, C. 2007. Kinetics of growth and bacteriocin production in Lb. casei RN 78n isolated from a dairy sample in Iran. International Journal of Dairy Sci. 2: 1-12.

Muñoz, A., Ananou, s., Gálvez, A., Martínez-Bueno, M., Rodríguez, A., Maqueda, M., Valdivia, E. 2007. Inhibition of Staphylococcus aureus in dairy products by enterocin AS-48 produced in situ and ex situ: bactericidal synergism through heat and AS-48. International Dairy Journal 17 (7):760-769.

Naidu, A.S., Bidlack, W.R., Clemens, R.A. 1999. Probiotic spectra of lactic acid bacteria (LAB). Crit. Rev. Food Science. Nutrition 38: 13-126.

Neha, G., Nivedita, S. 2009. Purification and characterization of bacteriocin produced by strain of Lactobacillus brevis MTCC 7539, Indian Journal of Biochemistry and Bio physiology. 46: 337-341.

Nemcova, R. 1997. Criteria for selection of Lactobacilli for probiotic use. Veterinary Medicine 42:19-27.

Ogunbanwo, S.T., Sanni, A., Onilude, A.A. 2003. Characterization of bacteriocin produced by Lactobacillus plantarum F1 and Lactobacillus brevis OG1. African Journal of Biotechnology 2 (8): 219-227.

O’Sullivan, L., Ross, R.P., Hill, C. 2002. Potential of bacteriocin-producing lactic acid bacteria for improvements in food safety and quality. Biochimie Journal 84: 593- 604.

Rajaram, G., Manivasagan, P., Thilagavathi, B., Saravanakumar, A. 2010. Purification and characterization of a bacteriocin produced by Lactobacillus lactis isolated from marine environment. Advanced Journal of Food Science and Technology. 2 (2): 138-144.

Rattanachaikunsopon, P., Phumkhachorn, P. 2006. Isolation and preliminary characterization of bacteriocin produced by Lactobacillus plantarum N014 isolated from Nham, traditional Thai fermented pork. Journal of Food Protection 69(8): 1937-1943.

Simova, E.D., Beshkova, D.B., Dimitorv, Zh.P. 2009. Characterization and antimicrobial spectrum of bacteriocins produced by lactic acid bacteria isolated from traditional Bulgarian dairy products. Journal of Applied Microbiology 106: 692-701.

Sullivan, A., Edlund, C., Nord, C.E.2001.Effect of antimicrobial agents on the ecological balance of human microflora. Lancet Infect Dis $1: 101-14$.

Todorov, S. D., Dicks, L. M. T. 2004. Comparison of two methods for purification of plantaricin ST31, a bacteriocin produced by Lactobacillus plantarum ST31.Enzyme Microbiology and Technology, 36: 318-326.

Todorov, S.D., Dicks, L.M.T. 2006. Screening for bacteriocin-producing lactic acid bacteria from boza, a traditional cereal beverage from Bulgaria comparison of the bacteriocins. Process of Biochemistry 41:11-19. 